\title{
Sistem Kendali Fuzzy Bertipe-2 Interval dengan Struktur Adaptif Beracuan Model
}

\author{
Bambang Riyanto ${ }^{1} \&$ Wakhyu Dwiono ${ }^{2}$ \\ ${ }^{1}$ Sekolah Teknik Elektro dan Informatika, Institut Teknologi Bandung \\ ${ }^{2}$ Program Studi Teknik Elektro FT, Univ. Muhammadiyah Purwokerto \\ E-mail : briyanto@lskk.ee.itb.ac.id
}

\begin{abstract}
Abstrak. Pengendali fuzzy adaptif merupakan pengendali fuzzy dengan parameter yang dapat berubah untuk menyesuaikan diri terhadap perubahan kondisi kendalian (plant). Dalam makalah ini disajikan rancangan dan implementasi struktur pengendali adaptif beracuan model. Pengendali logika fuzzy bertipe-2 interval dengan aksi menyerupai PD digunakan dan kinerjanya dievaluasi. Struktur pengendali fuzzy ini diterapkan pada pengendalian pendulum terbalik. Dari hasil simulasi dan eksperimen ditunjukkan bahwa dengan fungsi keanggotaan, kaidah fuzzy dan skala yang sama, pengendali fuzzy adaptif bertipe2 interval memiliki kinerja yang lebih baik jika dibandingkan dengan yang bertipe-1.
\end{abstract}

Kata kunci: sistem kendali; sistem fuzzy bertipe-2 interval; kendali adaptif dengan acuan model; pendulum terbalik.

\begin{abstract}
Adaptive fuzzy controller is a fuzzy controller that has ability to change its parameters when the plant's operating conditions vary. In this paper, design and implementation of model reference adaptive fuzzy control are presented. Interval type-2 fuzzy logic controller with PD-like action is employed and its performance is studied. The fuzzy controller structure is applied to control an inverted pendulum. Simulation and experimental study shows that by using similar membership function, fuzzy rules and scaling, interval type-2 adaptive fuzzy logic controller provides better control system performance compared to type-1 fuzzy controller.
\end{abstract}

Keywords: control system; interval type-2 fuzzy system; model reference adaptive control; inverted pendulum.

\section{Pendahuluan}

Tujuan fundamental sistem kendali adalah membawa trayektori sistem untuk mengikuti acuan yang diinginkan. Dalam merancang suatu sistem kendali, pengetahuan tentang plant adalah sangat penting. Dalam perancangan sistem kendali menggunakan metoda kendali klasik maupun modern, model dinamik plant perlu diketahui dengan baik karena metoda-metoda ini mendasarkan pada

Makalah diterima redaksi tanggal 20 Maret 2006, revisi diterima tanggal 31 Agustus 2006. 
model matematis[8,9]. Cara ini dikenal sebagai pendekatan analitis dalam perancangan sistem kendali.

Sistem kendali yang dirancang menggunakan metoda analitis dapat mengalami penurunan kinerja atau bahkan tidak stabil, bilamana terjadi perubahan parameter plant, nonlinieritas, ketidaksempurnaan dalam proses identifikasi, delay dari implementasi digital yang diabaikan dalam perancangan dan sebagainya. Dengan menggunakan pengendali yang dapat beradaptasi, dengan kata lain parameter kedali dapat ditala[7], trayektori sistem dapat dipertahankan mengikuti sinyal acuan yang dikehendaki.

Bilamana pengetahuan tentang plant terbatas, kendali fuzzy dapat merupakan alternatif yang efektif[2,10,11]. Metoda ini didasarkan pada cara penalaran manusia dalam mengolah informasi yang tidak tegas (kabur). Dalam hal ini, strategi kendali didasarkan pada cara bagaimana seorang pakar atau operator yang ahli mengendalikan sistem. Cara lain strategi kendali didasarkan pada prinsip respons ideal suatu sistem kendali terhadap masukan tangga, dan membangkitkan sinyal kendali yang sesuai dengan galat yang diamati [10,11]. Penelitian dalam kendali fuzzy sejauh ini difokuskan pada sistem fuzzy bertipe1, dimana fungsi keanggotaan memiliki bentuk yang tegas. Namun demikian, dalam praktek seringkali terdapat kekaburan dalam interpretasi sebuah himpunan fuzzy. Disamping itu, seringkali terdapat derau yang menyisipi data. Pada kasus seperti ini, sistem fuzzy berjenis ke-1 memiliki keterbatasan dalam merepresentasikan ketidakpastian tersebut. Dalam teori fuzzy, dikembangkan sistem fuzzy bertipe-2, diantaranya dengan fungsi keanggotaan berbentuk interval. Meskipun teori yang mendasari sistem fuzzy bertipe-2 telah diajukan [1,3-5], penerapannya dalam struktur kendali fuzzy adaptif belum diteliti dalam literatur. Terdapat dua kontribusi makalah ini dibandingkan literatur lain dalam sistem fuzzy bertipe-2[1,3-5,6] : 1) mengusulkan struktur kendali adaptif fuzzy bertipe-2 dengan acuan model, dan 2) melakukan kajian secara eksperimental impelementasinya dalam pengendalian pendulum terbalik.

Makalah ini diorganisasi sebagai berikut. Pada Bagian 2 diperkenalkan sistem fuzzy bertipe-2 dengan bentuk keanggotaan interval. Pada bagian ini juga disajikan struktur kendali adaptif fuzzy dengan acuan model. Pada Bagian 3 didiskusikan plant pendulum terbalik yang akan digunakan dalam sistem kendali. Pada Bagian 4 disajikan rancangan sistem kendali fuzzy. Pada Bagian 5 didiskusikan hasil simulasi kendali. Pada Bagian 6 disajikan hasil eksperimen. Kesimpulan disajikan pada Bagian 7. 


\section{Pengendali Fuzzy Adaptif Bertipe-2 Interval}

\subsection{Logika Fuzzy Bertipe-2 Interval}

Sistem logika fuzzy (SLF) bertipe-2 merupakan perluasan dari sistem logika fuzzy bertipe-1. Fungsi keanggotaan dalam sistem logika fuzzy bertipe-2 memiliki dua derajat keanggotaan, yaitu derajat keanggotaan primer dan sekunder (yang merupakan derajat keanggotaan dari derajat keanggotaan primer). Sedangkan derajat keanggotaan sekunder dalam sistem logika fuzzy bertipe-2 interval adalah bernilai 1 , yang digambarkan sebagai arsiran yang seragam seperti ditunjukkan pada Gambar 1. Selanjutnya bentuk semacam ini disebut FOU (footprint of uncertainty)[3].

Himpunan fuzzy bertipe-2 dinotasikan sebagai $\tilde{A}$, sedangkan derajat keanggotaan $x$ dalam $\tilde{A}$, dinotasikan dengan $\mu_{\tilde{A}}(x)$. Secara formal himpunan fuzzy bertipe-2 diekspresikan sebagai

$$
\mu_{\tilde{A}}(x)=\int_{u} f_{x}(u) / u, \quad u \in J \subseteq[0,1]
$$

Simbol $\int_{u}$ menyatakan himpunan derajad keanggotaan fuzzy. Operasi irisan dalam himpunan fuzzy bertipe-2 disebut meet, dinotasikan dengan $\cap$, sedangkan operasi gabungan disebut join dan dinotasikan dengan $U$.

Asumsikan sebuah sistem logika fuzzy bertipe-2 dengan kaidah dasar sebanyak $M$, setiap kaidah memiliki antecedent sebanyak $p$. Jika kaidah ke- $l$ dinotasikan $R^{l}$, sedemikian sehingga

$$
\begin{gathered}
R^{l}: \text { JIKA } x_{1} \text { adalah } \tilde{F}_{1}^{l}, x_{2} \text { adalah } \tilde{F}_{2}^{l}, \ldots \text {, dan } x_{p} \text { adalah } \tilde{F}_{p}^{l}, \\
\text { MAKA } y \text { adalah } \tilde{G}^{l}
\end{gathered}
$$

maka fungsi keanggotaan kaidah yang aktif $\mu_{\tilde{B}^{\prime}}(y)$, dituliskan berdasarkan kaidah komposisi sup-star yang diperluas sebagai

$$
\mu_{\tilde{B}^{l}}(y)=\bigcup_{x \in X}\left[\mu_{\tilde{A}_{x}}(x) \cap \mu_{\tilde{A}^{l} \rightarrow \widetilde{B}^{l}}(x, y)\right]
$$

dimana $X$ adalah ruang kartesian berdimensi $p$, yaitu $X=X_{I} \mathrm{x} \ldots \mathrm{x} X_{p}$, sedangkan $X_{k}$ adalah domain dari $x_{k},(k=1, \ldots, p)$ dan $\tilde{A}_{x}$ didefinisikan sebagai 


$$
\mu_{\tilde{A}_{x}}(x)=\mu_{\tilde{X}_{1} \times \cdots \times \tilde{X}_{p}}(x)=\mu_{\tilde{X}_{1}}\left(x_{1}\right) \cap \cdots \cap \mu_{\tilde{X}_{p}}\left(x_{p}\right)
$$

selanjutnya

$$
\mu_{\tilde{A}^{l} \rightarrow \tilde{G}^{l}}(x, y)=\mu_{\tilde{F}_{1}^{l}}\left(x_{1}\right) \mu_{\tilde{F}_{2}^{l}}\left(x_{2}\right) \cap \cdots \cap \mu_{\tilde{F}_{p}^{l}}\left(x_{p}\right) \mu_{\tilde{G}^{l}}(y) .
$$

Dengan mesubstitusikan Persamaan (4) dan (3) ke Persamaan (2), diperoleh

$$
\mu_{\tilde{B}^{l}}(y)=\mu_{\tilde{G}^{l}}(y)\left\{\bigcup_{x \in X}\left\{\begin{array}{l}
{\left[\mu_{\tilde{X}_{1}}\left(x_{1}\right) \cap \mu_{\tilde{F}_{1}^{l}}\left(x_{1}\right)\right] \cap} \\
\cdots \cap\left[\mu_{\tilde{X}_{p}}\left(x_{p}\right) \cap \mu_{\widetilde{F}_{p}^{l}}\left(x_{p}\right)\right]
\end{array}\right\}\right\}, \quad y \in Y .
$$

Dengan mengambil

$$
\mu_{\tilde{Q}_{k}^{l}}\left(x_{k}\right)=\mu_{\tilde{X}_{k}}\left(x_{k}\right) \cap \mu_{\tilde{F}_{k}^{l}}\left(x_{k}\right),
$$

maka

$$
\mu_{\widetilde{B}^{l}}(y)=\mu_{\widetilde{G}^{l}}(y) \cap\left\{\bigcup_{x \in X}\left[\bigcup_{k=1}^{p} \mu_{\widetilde{Q}_{k}^{l}}\left(x_{k}\right)\right]\right\}, \quad y \in Y
$$

Dengan menganggap terdapat $N$ buah kaidah yang aktif dari $M$ buah kaidah yang ada, maka

$$
\mu_{\tilde{B}}(y)=\bigcup_{l=1}^{N} \mu_{\widetilde{B}^{l}}(y), \quad y \in Y
$$

Selanjutnya, dengan mengambil

$$
\mu_{\tilde{Q}^{l}}(x)=\bigcap_{k=1}^{p} \mu_{\tilde{Q}_{k}^{l}}\left(x_{k}\right)
$$

dan

$$
F^{l}=\bigcup_{x \in X}\left[\bigcap_{k=1}^{p} \mu_{\tilde{Q}_{k}^{l}}\left(x_{k}\right)\right]=\bigcup_{x \in X} \mu_{\tilde{Q}^{l}}(x)
$$

maka Persamaan (6) menjadi

$$
\mu_{\widetilde{B}^{l}}(y)=\mu_{\widetilde{G}^{l}}(y) \cap F^{l}, \quad y \in Y .
$$

Secara umum beban komputasi sistem logika fuzzy bertipe-2 lebih tinggi dibandingkan tipe-1. Proses komputasi menjadi lebih sederhana jika fungsi keanggotaan yang digunakan bertipe interval. 


\subsection{Operasi Meet dan Join untuk Himpunan Interval}

\subsubsection{Operasi Meet Himpunan Interval}

Misalkan $F=\int_{v \in F} 1 / v$ dan $G=\int_{w \in G} 1 / w$ adalah dua himpunan interval bertipe-1 dengan domain $v \in\left[l_{f}, r_{f}\right]\left(\left[l_{f}, r_{f}\right] \subseteq[0,1]\right)$ dan $w \in\left[l_{g}, r_{g}\right]\left(\left[l_{g}, r_{g}\right] \subseteq[0,1]\right)$, maka operasi meet antara $F$ dan $G$ adalah: $Q=F \cap G\left(Q=\int_{v \in Q} 1 / q\right)$, yang dalam t-norm minimum (perkalian) didefinisikan sebagai

$$
Q=F \cap G=\int_{q \in\left[l_{f} * l_{g}, r_{f} * r_{g}\right]} 1 / q
$$

dimana $q=v * w$.

Operasi meet dari dua himpunan fuzzy bertipe-2 interval, secara grafis dapat dilihat pada Gambar 1.

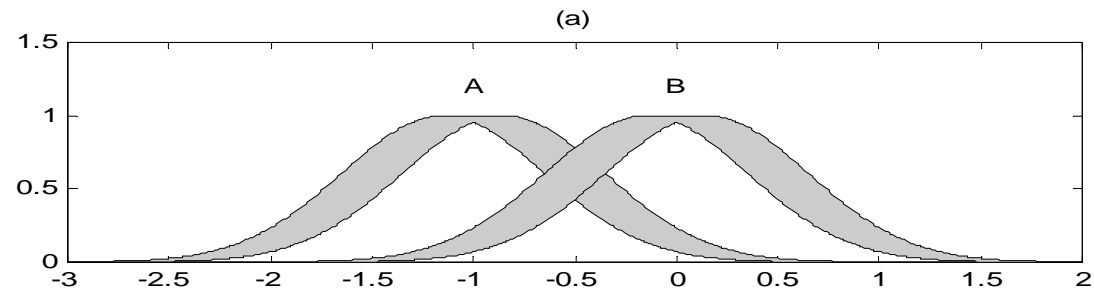

(b)

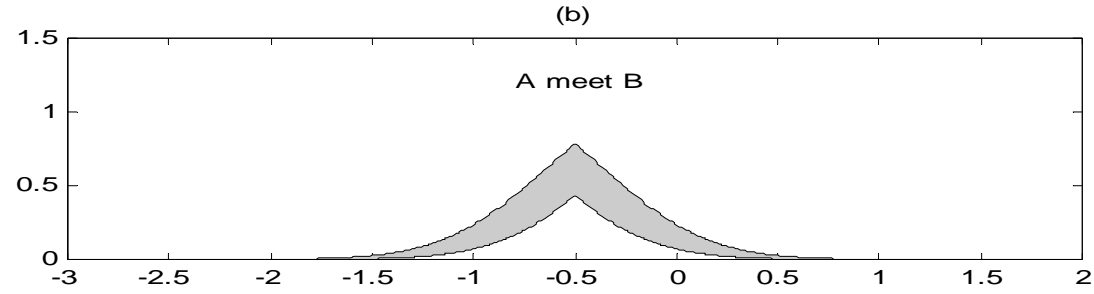

Gambar 1 Operasi meet pada himpunan fuzzy bertipe-2 interval, (a) himpunan fuzzy $A$ dan $B$, (b) $A \cap B$.

\subsubsection{Operasi Join Himpunan Interval}

Misalkan himpunan $F$ dan $G$ seperti telah didefinisikan pada bagian sebelumnya, maka operasi join antara $F$ dan $G$ adalah $Q=F \cup G\left(Q=\int_{v \in Q} 1 / q\right)$ yang didefinisikan sebagai berikut: 


$$
Q=F \bigcup G=\int_{q \in\left[l_{f} \vee l_{g}, r_{f} \vee r_{g}\right]} 1 / q
$$

dimana $q=v \vee w$.

Operasi join dari dua himpunan fuzzy bertipe-2 interval secara grafis dapat dilihat pada Gambar 2.

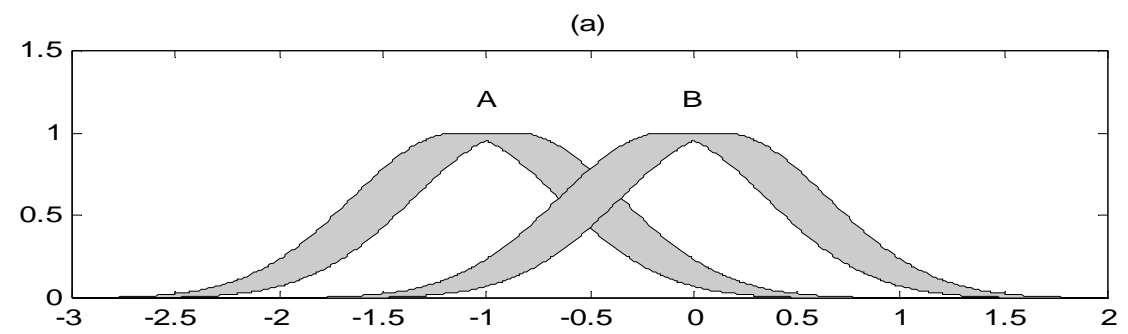

(b)

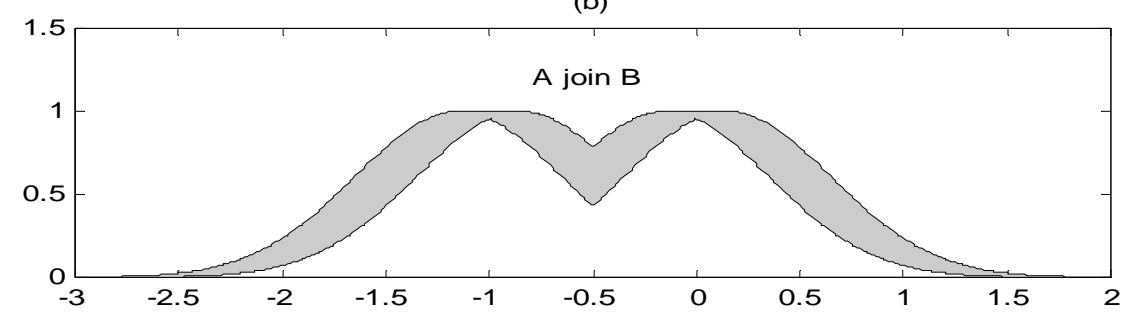

Gambar 2 Operasi join pada himpunan fuzzy tipe 2 interval, (a) himpunan fuzzy $A$ dan $B$, (b) $A \bigcup B$.

\subsection{Fungsi Keanggotaan Bagian Atas dan Bagian Bawah}

Footprint of uncertainty (FOU) adalah daerah terbatas yang memuat ketidakpastian derajat keanggotaan primer dari fungsi keanggotaan bertipe 2 . Fungsi keanggotaan bagian atas dan bagian bawah merupakan dua buah fungsi keanggotaan bertipe-1 yang membatasi footprint of uncertainty fungsi keanggotaan interval bertipe-2. Fungsi keanggotaan bagian atas adalah himpunan bagian yang memiliki derajat keanggotaan tertinggi dalam FOU, sedangkan fungsi keanggotaan bagian bawah adalah sebaliknya.

Gambar 3 memperlihatkan salah satu contoh bentuk fungsi keanggotaan himpunan fuzzy bertipe-2 interval (fungsi Gauss dengan pergeseran titik tengah), Daerah yang diarsir merupakan FOU. Fungsi keanggotaan dalam Gambar 3 didefinisikan sebagai berikut: 


$$
\mu_{k}^{l}\left(x_{k}\right)=\exp \left[-\frac{1}{2}\left(\frac{x_{k}-m_{k}^{l}}{\sigma_{k}^{l}}\right)^{2}\right], \quad m_{k}^{l} \in\left[m_{k 1}^{l}, m_{k 2}^{l}\right]
$$

dengan $k=(1, \ldots, p)$ adalah jumlah antecedent, $l=(1, \ldots, M)$ adalah jumlah kaidah.

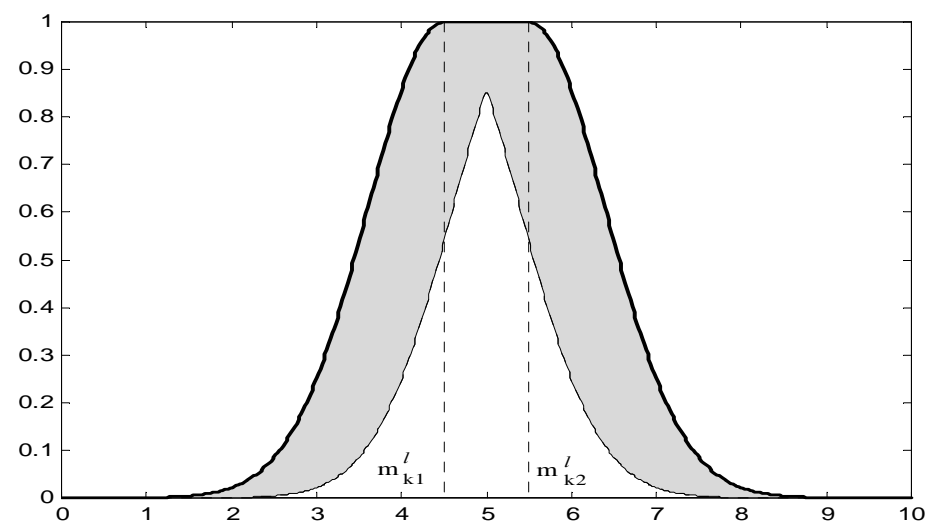

Gambar 3 Fungsi keanggotaan interval bertipe-2, garis tebal adalah fungsi keanggotaan bagian atas, sedangkan garis tipis adalah fungsi keanggotaan bagian bawah.

Dengan mengambil

$$
N\left(m_{k 1}^{l}, \sigma_{k}^{l} ; x_{k}\right) \cong \exp \left(-\frac{1}{2}\left(\frac{x_{k}-m_{k 1}^{l}}{\sigma_{k}^{l}}\right)^{2}\right)
$$

maka fungsi keanggotaan bagian atas didefinisikan sebagai berikut:

$$
\bar{\mu}_{k}^{l}\left(x_{k}\right)=\left\{\begin{array}{l}
N\left(m_{k 1}^{l}, \sigma_{k}^{l} ; x_{k}\right), \quad x_{k}<m_{k 1}^{l} \\
1, \quad m_{k 1}^{l} \leq x_{k} \leq m_{k 2}^{l} \\
N\left(m_{k 2}^{l}, \sigma_{k}^{l} ; x_{k}\right), \quad x_{k}>m_{k 2}^{l}
\end{array}\right.
$$

Sedangkan fungsi keanggotaan bagian bawah didefinisikan sebagai berikut:

$$
\underline{\mu}_{k}^{l}\left(x_{k}\right)= \begin{cases}N\left(m_{k 1}^{l}, \sigma_{k}^{l} ; x_{k}\right), & x_{k} \leq \frac{m_{k 1}^{l}+m_{k 2}^{l}}{2} \\ N\left(m_{k 2}^{l}, \sigma_{k}^{l} ; x_{k}\right), & x_{k}>\frac{m_{k 1}^{l}+m_{k 2}^{l}}{2}\end{cases}
$$


Untuk selanjutnya, fungsi keanggotaan bagian atas dan bagian bawah ditandai dengan tanda garis atas dan garis bawah. Sebagai contoh fungsi keanggotaan bagian atas dari $\mu_{\tilde{Q}_{k}^{l}}\left(x_{k}\right)$ adalah $\bar{\mu}_{\tilde{Q}_{k}^{l}}\left(x_{k}\right)$ dan bagian bawah adalah $\underline{\mu}_{\tilde{Q}_{k}^{l}}\left(x_{k}\right)$, sehingga

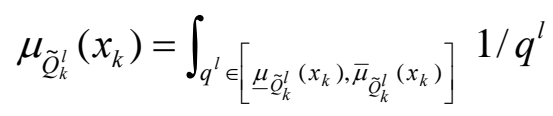

dengan cara yang sama, maka $\mu_{\tilde{X}_{k}}\left(x_{k}\right)$ dan $\mu_{\tilde{F}_{k}}\left(x_{k}\right)$ dapat ditulis menjadi

$$
\begin{aligned}
& \mu_{\tilde{X}_{k}}\left(x_{k}\right)=\int_{v^{l} \in\left[\mu_{X_{k}}\left(x_{k}\right), \bar{\mu}_{X_{k}}\left(x_{k}\right)\right]} 1 / v^{l} \\
& \mu_{\tilde{F}_{k}^{l}}\left(x_{k}\right)=\int_{w^{l} \in\left[\underline{\mu}_{F_{k}^{l}}\left(x_{k}\right), \bar{\mu}_{F_{k}^{l}}\left(x_{k}\right)\right]} 1 / w^{l}
\end{aligned}
$$

\subsection{Sistem Logika Fuzzy Bertipe-2 Interval}

\subsubsection{Fuzzifikasi dan Inferensi}

Pada sistem logika fuzzy, jika sinyal/informasi masukan di-fuzzifikasi menggunakan himpunan fuzzy bertipe-2 interval maka $F^{l}$ pada Persamaan (9) merupakan himpunan interval bertipe-1 [1,3-5], yakni $F^{l}=\left[f^{l}, \bar{f}^{l}\right]$, dimana

$$
\underline{f}^{l}=\sup _{x \in X} \int_{X_{1}} \cdots \int_{X_{p}}\left[\underline{\mu}_{\tilde{X}_{1}}\left(x_{1}\right) * \underline{\mu}_{\tilde{F}_{k}^{l}}\left(x_{1}\right)\right] * \cdots *\left[\underline{\mu}_{\tilde{X}_{p}}\left(x_{p}\right) * \underline{\mu}_{\widetilde{F}_{k}^{l}}\left(x_{p}\right)\right] / x
$$

dan

$$
\bar{f}^{l}=\sup _{x \in X} \int_{X_{1}} \cdots \int_{X_{p}}\left[\bar{\mu}_{\widetilde{X}_{1}}\left(x_{1}\right) * \bar{\mu}_{\widetilde{F}_{k}^{l}}\left(x_{1}\right)\right] * \cdots *\left[\bar{\mu}_{\widetilde{X}_{p}}\left(x_{p}\right) * \bar{\mu}_{\widetilde{F}_{k}^{l}}\left(x_{p}\right)\right] / x
$$

(lihat Gambar 6). Kaidah $R^{l}$ mengaktifkan himpunan konsekuen dengan derajat keanggotaan sebagai berikut (dari Persamaan (10)),

$$
\mu_{\widetilde{B}^{l}}(y)=\int_{b^{l} \in\left[\tilde{f}^{l} * \underline{\underline{G}}_{\tilde{\sigma}^{l}}(y), \bar{f}^{l} * \bar{\mu}_{\tilde{G}^{l}}(y)\right]} 1 / b^{l}
$$

dimana $\underline{\mu}_{\widetilde{G}^{l}}(y)$ dan $\bar{\mu}_{\widetilde{G}^{l}}(y)$ adalah fungsi keanggotaan bagian bawah dan bagian atas dari $\mu_{\widetilde{G}^{l}}(y)$. Agregasi himpunan fuzzy $\mu_{\widetilde{B}}(y)$ diberikan oleh (dari Persamaan (7)) 


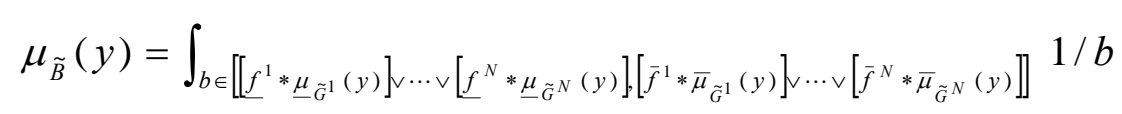

Jika masukan di-fuzzifikasi menggunakan himpunan fuzzy bertipe-1, maka $\mu_{\tilde{X}_{k}} \rightarrow \mu_{X_{k}}(k=1, \cdots, p)$, yaitu fungsi keanggotaan bagian atas dan bagian bawah digabung sehingga

$$
\underline{f}^{l}=\sup _{x \in X} \int_{X_{1}} \cdots \int_{X_{p}}\left[\mu_{X_{1}}\left(x_{1}\right) * \underline{\mu}_{\widetilde{F}_{1}^{l}}\left(x_{1}\right)\right] * \cdots *\left[\mu_{X_{p}}\left(x_{p}\right) * \underline{\mu}_{\tilde{F}_{p}^{l}}\left(x_{p}\right)\right] / x
$$

dan

$$
\bar{f}^{l}=\sup _{x \in X} \int_{X_{1}} \cdots \int_{X_{p}}\left[\mu_{X_{1}}\left(x_{1}\right) * \bar{\mu}_{\widetilde{F}_{1}^{l}}\left(x_{1}\right)\right] * \cdots *\left[\mu_{X_{p}}\left(x_{p}\right) * \bar{\mu}_{\widetilde{F}_{p}^{l}}\left(x_{p}\right)\right] / x
$$

Proses ini dapat dilihat pada Gambar 5.

Dalam sistem logika fuzzy bertipe-2 interval dengan fuzzifikasi singleton, operasi meet didefinisikan menggunakan t-norm minimum atau perkalian, sehingga dalam kasus ini nilai $\underline{f^{l}}$ dan $\bar{f}^{l}$ adalah [1,3-5]

$$
\underline{f}^{l}=\underline{\mu}_{\widetilde{F}_{1}^{l}}\left(x_{1}\right) * \cdots * \underline{\mu}_{\widetilde{F}_{p}^{l}}\left(x_{p}\right)
$$

dan

$$
\bar{f}^{l}=\bar{\mu}_{\tilde{F}_{1}^{l}}\left(x_{1}\right) * \ldots * \bar{\mu}_{\tilde{F}_{p}^{l}}\left(x_{p}\right)
$$

dimana $x_{i}(i=1 \cdots p)$ menunjukan lokasi singleton. Proses ini dapat dilihat pada Gambar 4.
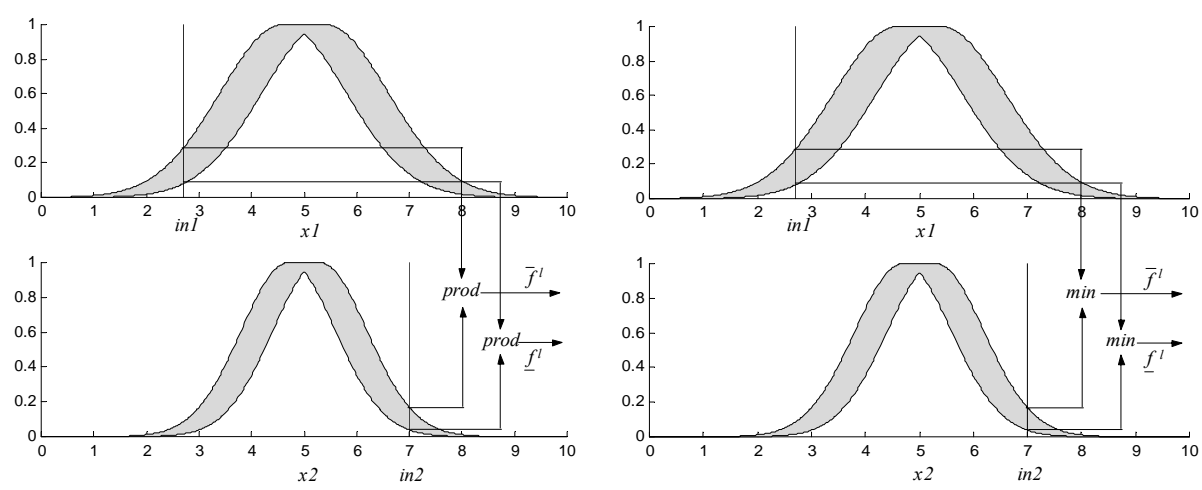

Gambar 4 Operasi meet pada SLF bertipe-2 interval menggunakan operasi minimum dan perkalian untuk singleton bertipe-1. 

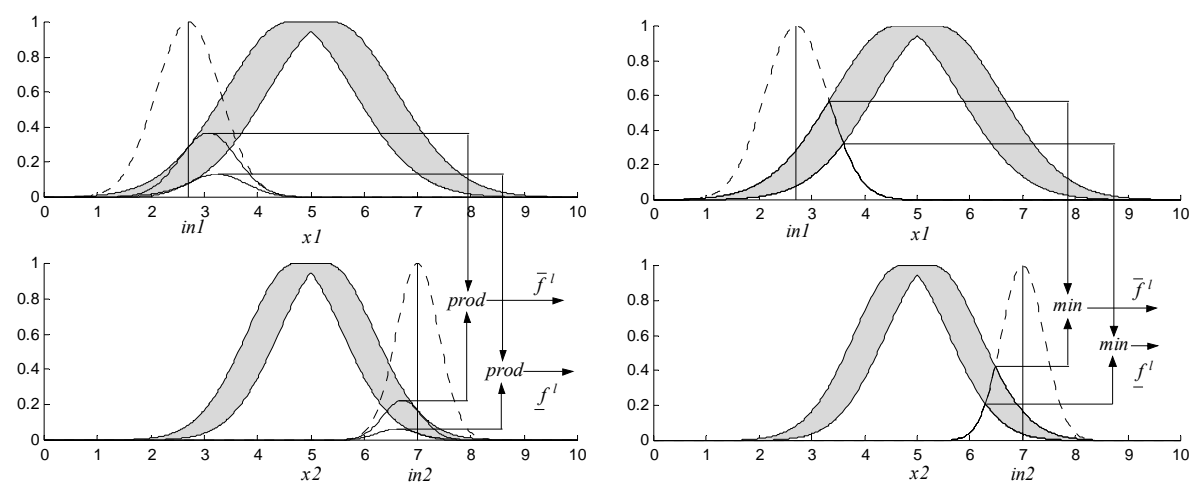

Gambar 5 Operasi meet pada SLF bertipe-2 interval menggunakan operasi minimum dan perkalian untuk nonsingleton bertipe-1.
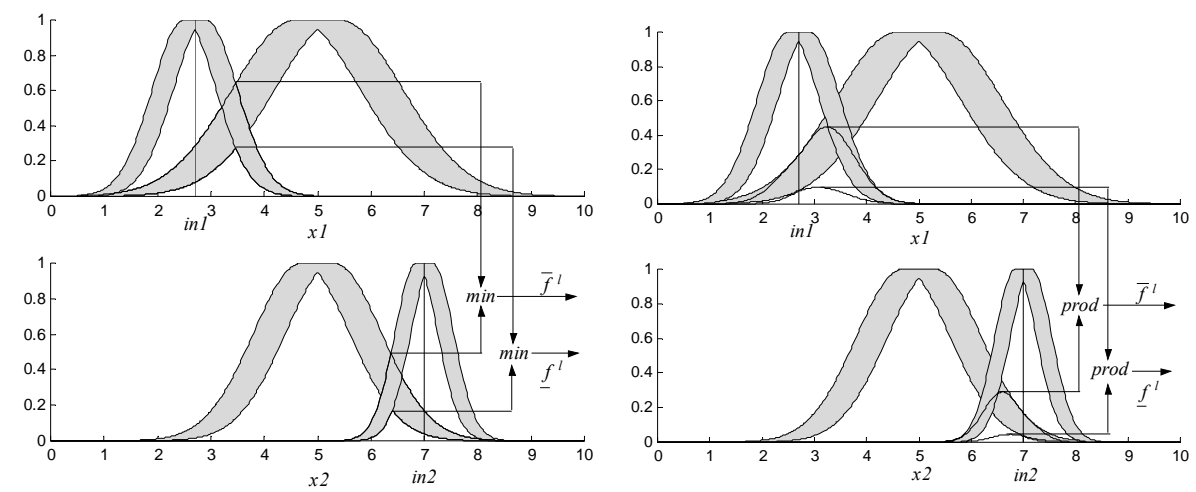

Gambar 6 Operasi meet pada SLF bertipe-2 interval menggunakan operasi minimum dan perkalian untuk nonsingleton bertipe-2.

\subsubsection{Reduksi tipe dan defuzzifikasi}

Setelah melewati proses fuzzifikasi, inferensi fuzzy, reduksi tipe dan defuzzifikasi, keluaran SLF bertipe-2 merupakan besaran nyata. Ada beberapa cara mereduksi tipe, diantaranya adalah centroid, height dan center of set. Secara umum keluaran dari SLF bertipe-2 interval adalah

$$
Y\left(Z_{1}, \cdots, Z_{M}, W_{1}, \cdots, W_{M}\right)=\int_{Z_{1}} \cdots \int_{Z_{M}} \int_{W_{1}} \cdots \int_{W_{M}} 1 / \frac{\sum_{l=1}^{M} w_{l} z_{l}}{\sum_{l=1}^{M} w_{l}}
$$


Setiap $Z_{l}(l=1, \ldots, M)$ adalah himpunan bertipe 1 interval, yang memiliki pusat $c_{l}$ dan lebar (spread) $s_{l}\left(s_{l} \geq 0\right)$. Setiap $W_{l}$ juga merupakan himpunan tipe 1 interval yang memiliki pusat $h_{l}$ dan lebar (spread) $\Delta_{l}\left(\Delta_{l} \geq 0\right)$, dengan anggapan $h_{l} \geq \Delta_{l}$ sehingga $w_{l} \geq 0$ untuk $l=1, \ldots, M$. Demikian juga $Y$ merupakan himpunan bertipe 1 interval, sehingga evaluasi dilakukan pada titik paling kiri $\left(y_{k i}\right)$ dan paling kanan $\left(y_{k a}\right)$. Nilai $y_{k i}$ memiliki ketergantungan terhadap nilai $c_{l}-s_{l}$ dan salah satu titik batas dari $W_{i}$, sedangkan nilai $y_{k a}$ tergantung pada nilai $c_{l}+s_{l}$ dan salah satu titik batas dari $W_{i}$. Komputasi berikut digunakan selama iterasi dalam menghitung nilai $y_{k i}$ dan $y_{k a}$.

$$
S\left(w_{1}, \ldots, w_{M}\right) \cong \frac{\sum_{l=1}^{M} w_{l} z_{l}}{\sum_{l=1}^{M} w_{l}}
$$

dengan $w_{l} \in\left[h_{l}-\Delta_{l}, h_{l}+\Delta_{l}\right]$ dan $h_{l} \geq \Delta_{l}$ untuk $l=1, \ldots, M$ sedangkan $z_{l} \in\left[c_{l}-\mathrm{s}_{l}, c_{l}+\mathrm{s}_{l}\right]$. $S$ memiliki nilai maksimum pada $y_{k a}$. Untuk menghitung $y_{k a}$, pertama kita menggunakan $z_{l}=c_{l}+\mathrm{s}_{l}$ untuk $(l=1, \ldots, M)$ dengan tanpa menghilangkan asas umum, $z_{l}$ dianggap telah tersusun dari nilai terkecil hingga terbesar, yaitu $z_{1} \leq z_{2}$ $\leq \ldots \leq z_{M}$. Langkah selanjutnya adalah:

1. menghitung $S^{\prime}=S\left(h_{1}, \ldots, h_{M}\right)$ menggunakan Persamaan (29), dengan $w_{l}=h_{l}$ untuk $l=1, \ldots, M$;

2. mencari $k(1 \leq k \leq M-1)$ demikian sehingga $z_{k} \leq S^{\prime} \leq z_{k+1}$;

3. menghitung $S^{\prime \prime}=S\left(h_{1}-\Delta_{1}, \ldots, h_{k}-\Delta_{k}, h_{k+1}+\Delta_{k+1}, \ldots, h_{M}+\Delta_{M}\right)$ menggunakan Persamaan (29), dengan $w_{l}=h_{l}-\Delta_{l}$ untuk $l \leq k$ dan $w_{l}=h_{l}+\Delta_{l}$ untuk $l \geq$ $k+1$;

4. memeriksa apakah $S^{\prime \prime}=S^{\prime}$, jika ya maka iterasi berhenti; jika tidak, selanjutnya ke langkah 5;

5. mengganti nilai $S^{\prime}$ dengan $S^{\prime \prime}$, selanjutnya ke langkah 2.

Nilai minimum $S\left(w_{1}, \ldots, w_{M}\right)$ yaitu $y_{k i}$, dapat dihitung menggunakan prosedur yang sama seperti langkah di atas. Hanya ada dua perubahan yaitu menggunakan $z_{l}=c_{l}$ - $\mathrm{S}_{l}$ untuk $(l=1, \ldots, M)$. Selanjutnya pada langkah 3 , untuk menghitung $S^{\prime \prime}=S\left(h_{1+} \Delta_{1}, \ldots, h_{k}+\Delta_{k}, h_{k+1}-\Delta_{k+1}, \ldots, h_{M}-\Delta_{M}\right)$ digunakan $w_{l}=h_{l}+\Delta_{l}$ untuk $l \leq k$ dan $w_{l}=h_{l}-\Delta_{l}$ untuk $l \geq k+1$. Prosedur ini dapat digunakan untuk semua jenis pereduksi.

1. Reduksi Centroid

Nilai yang dievaluasi dalam pereduksi ini adalah hasil join dari antecedent kaidah yang aktif. Dengan menggunakan prosedur di atas, maka $M$ adalah banyaknya diskritisasi semesta pembicaraan $Y$ sehingga $Y\left(y_{1}, \ldots, y_{M}\right), c_{l}=y_{i}$; 
$s_{l}=0 . \mu_{\tilde{B}}\left(y_{i}\right)$ memiliki domain $\left[L_{i}, R_{i}\right]$, sehingga $h_{l}=\left(L_{i}+R_{i}\right) / 2$ dan $\Delta_{l}=\left(R_{i}\right.$ $\left.-L_{i}\right) / 2$.

$$
Y_{c}(x)=\int_{\theta_{1}} \cdots \int_{\theta_{N}} 1 / \frac{\sum_{i=1}^{M} y_{i} \theta_{i}}{\sum_{i=1}^{M} \theta_{i}}
$$

2. Reduksi Ketinggian

Reduksi ketinggian dihitung melalui

$$
Y_{h}(x)=\int_{\theta_{1}} \cdots \int_{\theta_{M}} 1 / \frac{\sum_{l=1}^{M} \bar{y}^{l} \theta_{l}}{\sum_{l=1}^{M} \theta_{l}}
$$

$\bar{y}^{l}$ adalah titik dalam semesta pembicaran $Y$ yang memiliki nilai derajat keanggotaan paling tinggi dalam kaidah ke- $l$. Untuk menggunakan prosedur reduksi di atas, maka $c_{l}=\bar{y}^{l}, s_{l}=0 . \mu_{\tilde{B}}\left(\bar{y}^{l}\right)$ memiliki domain $\left[L_{l}, R_{l}\right]$, sehingga $h_{l}=\left(L_{l}+R_{l}\right) / 2$ dan $\Delta_{l}=\left(R_{l}-L_{l}\right) / 2$.

3. Reduksi Pusat Himpunan

Untuk pereduksi jenis ini, yang pertama dilakukan adalah mencari nilai centroid $\left(C_{l}\right)$ dari himpunan interval konsekuen setiap kaidah yang aktif. Domain dari $C_{l}$ adalah $\left[L_{l}^{c}, R_{l}^{c}\right]$, sehingga $c_{l}=\left(L_{l}^{c}+R_{l}^{c}\right) / 2$, $s_{l}=\left(R_{l}^{c}-L_{l}^{c}\right) / 2$ sedangkan domain derajat keanggotaan konsekuen-nya adalah $\left[L_{l}, R_{l}\right]$, sehingga $h_{l}=\left(L_{l}+R_{l}\right) / 2$ dan $\Delta_{l}=\left(R_{l}-L_{l}\right) / 2$.

Nilai tegas yang diperoleh dari ketiga jenis pereduksi adalah

$$
y=\frac{y_{k i}+y_{k a}}{2}
$$

\subsection{Struktur Fuzzy Adaptif Acuan Model}

Pengendali fuzzy adaptif acuan model merupakan pengendali dengan parameter yang dapat diubah, serta memiliki mekanisme untuk proses penalaan parameternya berdasarkan model acuan yang digunakan. Model acuan ini merepresentasikan perilaku sistem lingkar tertutup yang ingin dihasilkan. Dalam struktur pengendali jenis ini, tidak diperlukan identifikasi sistem. 
Parameter yang ditala dalam proses adaptif adalah titik tengah fungsi keanggotaan konsekuen. Struktur pengendali jenis ini ditampilkan pada Gambar 7.

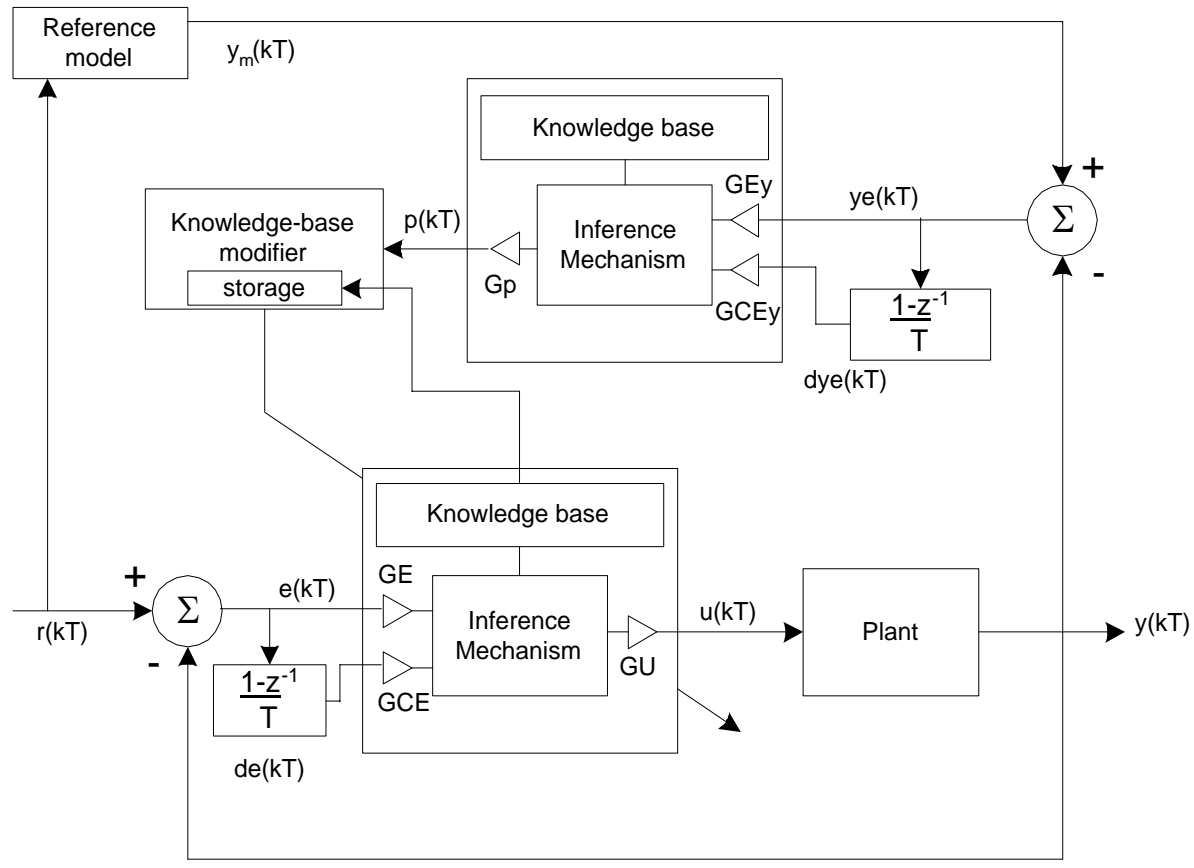

Gambar 7 Blok pengendali fuzzy adaptif acuan model [11].

Secara garis besar proses adaptasi tersebut terjadi dalam dua langkah, yaitu:

1. Menentukan seluruh kaidah yang aktif ketika proses pengendalian berlangsung. Kaidah yang aktif dikenali dengan hasil minimum dari $(\mu(e(k T-T), c(k T-T))>0$.

2. Menala titik tengah fungsi keanggotaan kaidah yang aktif dengan menambahkan $p(k T)$. Jika mula-mula titik tengah bernilai $b_{m}$, maka setelah dilakukan pergeseran diperoleh $b_{m}(k T)=b_{m}(k T-T)+p(k T)$, selanjutnya hasilnya disimpan sebagai basis kaidah yang baru.

\section{$3 \quad$ Plant Pendulum Terbalik}

Dalam makalah ini disajikan penerapan sistem kendali adaptif fuzzy bertipe 2 pada plant pendulum terbalik. Pendulum terbalik dipilih berdasarkan dua pertimbangan: 1) model plant bersifat nonlinier dan 2) telah menjadi benchmark 
dalam literatur sistem kendali. Perangkat keras sistem pendulum terbalik diperlihatkan pada Gambar 8. Tujuan pengendalian dalam sistem ini adalah untuk menjaga sudut pendulum pada 0 rad serta posisi cart pada 0 meter dengan massa pendulum yang tetap. Sistem kendali untuk pendulum terbalik ini menggunakan dua buah sensor dalam bentuk encoder, masing-masing untuk mengukur besarnya sudut pendulum dan posisi cart. Dua buah counter, masingmasing terdiri atas 12 bit, digunakan untuk akuisisi data pengukuran ini ke PC. Aktuator sistem kendali berupa motor dengan gear yang akan menggerakkan cart. Sinyal kendali ke aktuator ini dibangkitkan oleh PC melalui DAC dan penguat elektronik(AMP).

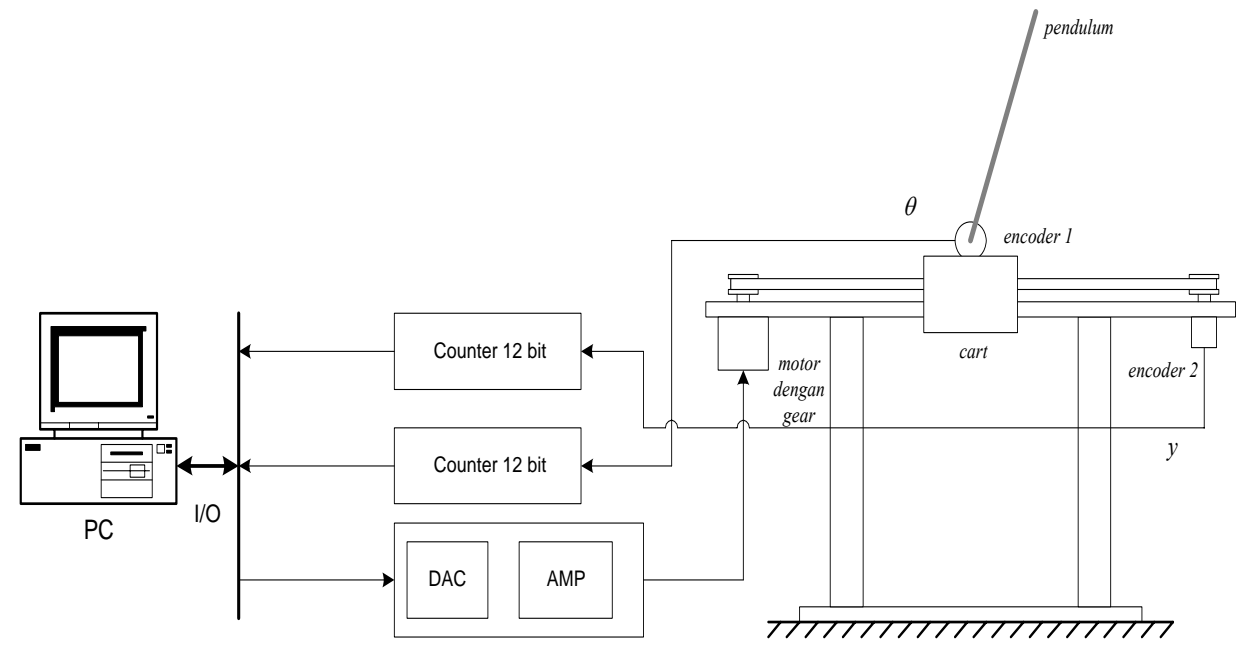

Gambar 8 Plant pendulum terbalik.

Sistem pendulum terbalik memiliki persamaan dinamik sebagai berikut :

$$
\begin{aligned}
& (M+m) \ddot{r}+m l \ddot{\theta} \cos \theta-m l \dot{\theta}^{2} \sin \theta+C_{c} \dot{r}=k_{t} u \\
& m l^{2} \ddot{\theta}+J \ddot{\theta}+m l \ddot{r} \cos \theta+C_{p} \dot{\theta}-m g l \sin \theta=0
\end{aligned}
$$

dimana:

$g$ : gravitasi bumi $\left(\mathrm{m} . \mathrm{s}^{-2}\right)$

$l:$ jarak pusat ke titik massa pendulum (m)

$C_{p}$ : konstanta gesekan rotasi $\left(\mathrm{kg} \cdot \mathrm{m}^{2} \cdot \mathrm{s}^{-1}\right)$

$C_{c}$ : konstanta gesekan translasi $\left(\mathrm{kg} . \mathrm{s}^{-1}\right)$

$m$ : massa pendulum $(\mathrm{kg})$

$r$ : posisi cart $(\mathrm{m})$

$\theta$ : sudut pendulum (rad)

$k_{t}$ : konstanta torsi (N/volt) 
$u$ : tegangan yang diberikan ke motor (volt).

Nilai parameter yang terlibat pada Persamaan (33) dan (34) diperlihatkan pada Tabel 1.

Tabel 1 Parameter pendulum terbalik.

\begin{tabular}{|c|l|l|}
\hline Parameter & Pengertian & Nilai \\
\hline $\mathrm{M}$ & Massa sistem cart & $1,96 \mathrm{~kg}$ \\
\hline$k_{t}$ & Penguatan torsi & $0,98 \mathrm{~N} / \mathrm{V}$ \\
\hline$C_{c}$ & Koefisien gesekan translasi & $16,3 \mathrm{~kg} / \mathrm{s}$ \\
\hline$J$ & Inersia & $0,000447 \mathrm{~kg} . \mathrm{m}^{2}$ \\
\hline$l$ & Jarak antara titik massa ke pusat & $0,125 \mathrm{~m}$ \\
\hline$C_{p}$ & Koefisien gesekan rotasi & $0,000402 \mathrm{~kg} \cdot \mathrm{m}^{2} / \mathrm{s}$ \\
\hline$m$ & Massa pendulum & $0,045 \mathrm{~kg}$ \\
\hline$g$ & Percepatan gravitasi & $9,8 \mathrm{~m} / \mathrm{s}^{2}$ \\
\hline
\end{tabular}

\section{Rancangan Pengendali Fuzzy}

Pengendali fuzzy adaptif dirancang berdasarkan diagram blok seperti pada Gambar 10. Sistem logika fuzzy yang digunakan sebagai pengendali maupun mekanisme adaptasi memiliki kaidah dan fungsi keanggotaan yang sama, hanya berbeda dalam skala penguatannya. Fungsi keanggotaan yang digunakan memiliki bentuk seperti diperlihatkan pada Gambar 9. Fungsi keanggotaan masukan berbetuk interval dan semesta pembicaraannya dipartisi menjadi tiga buah set fuzzy yang mewakili Negative (N), Zero(Z) dan Positive(P). Fungsi keanggotaan keluaran berbetuk singleton, masing-masing mewakili Negative (N), Zero(Z) dan Positive(P). Kaidah fuzzy dikonstruksi seperti pada Tabel 2. Kaidah fuzzy ini mencerminkan strategi kendali secara kualitatif untuk mencapai respons sistem lingkar tertutup yang ideal.
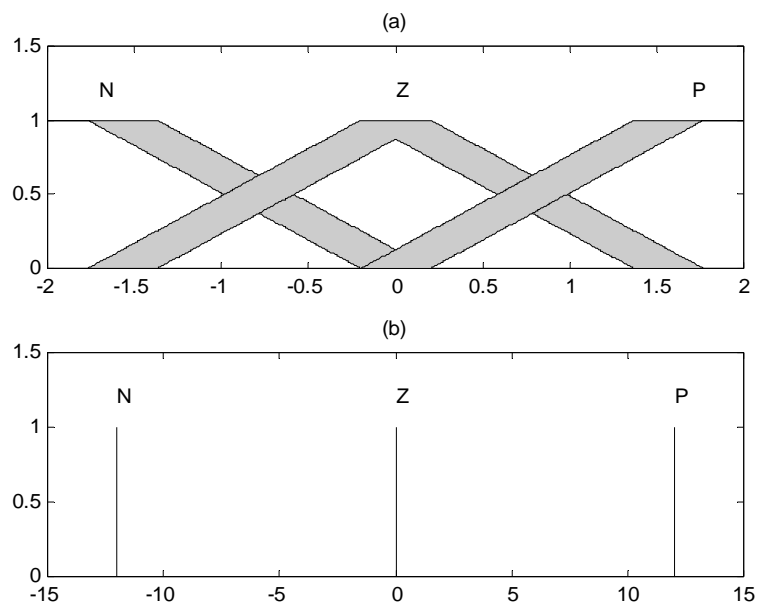

Gambar 9 Fungsi keanggotaan masukan dan keluaran. 
Tabel 2 Kaidah fuzzy.

\begin{tabular}{l|c|c|c|c|}
\multicolumn{4}{c|}{ Perubahan Error } \\
\hline & $\mathbf{N}$ & $\mathbf{Z}$ & $\mathbf{P}$ \\
\hline $\mathbf{N}$ & $\mathrm{N}$ & $\mathrm{N}$ & $\mathrm{Z}$ \\
\hline $\mathbf{N}$ & $\mathrm{N}$ & $\mathrm{Z}$ & $\mathrm{P}$ \\
\hline $\mathbf{P}$ & $\mathrm{Z}$ & $\mathrm{P}$ & $\mathrm{P}$ \\
\hline
\end{tabular}

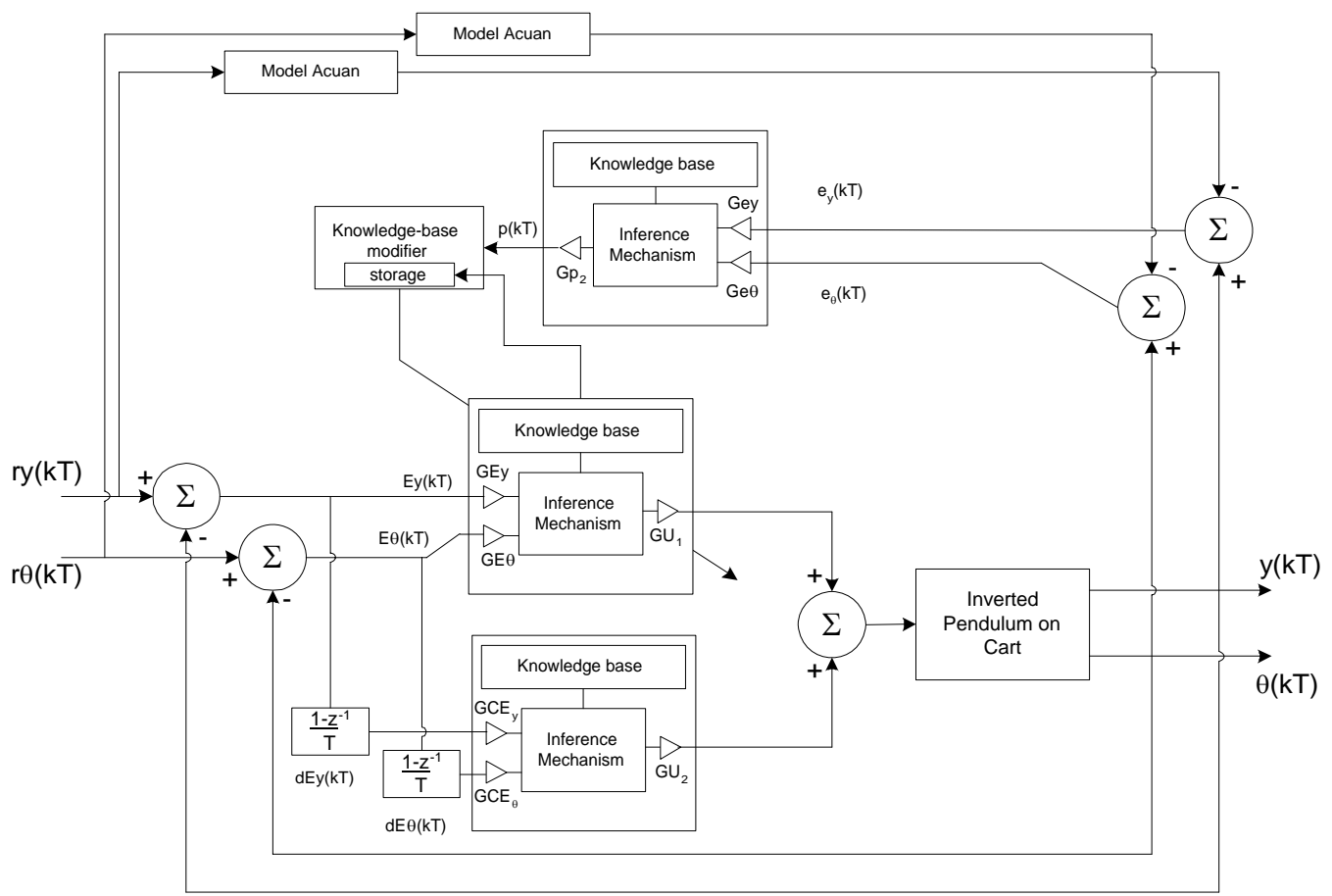

Gambar 10 Blok sistem kendali fuzzy adaptif.

\section{$5 \quad$ Hasil Simulasi}

Besarnya penguatan untuk pengendali fuzzy (arah maju) adalah $G E_{\theta}=5,19$, $G E_{y}=5 ; G U 1=-2,5 ; \quad G C E_{\theta}=2,75, G C E_{y}=0,75 ;$ dan $G U 2=-2.5$. Sedangkan penguatan untuk mekanisme adaptasi (sistem fuzzy dengan arah mundur) adalah $G e_{\theta}=5,19, G e_{y}=5 ; G p 2$ (konstanta adaptasi)=0.002. Lebar pita fungsi keanggotaan fuzzy bertipe-2 interval adalah 0 ,3. Hasil simulasi ditampilkan dalam Gambar 11. Pada gambar ini ditampilkan respons sistem kendali adaptif 
fuzzy bertipe-1 dan bertipe-2. Kinerja yang dihasilkan oleh sistem kendali ditampilkan pada Tabel 3.

Pengendali adaptif fuzzy bertipe-2 interval memiliki kinerja yang lebih baik dari yang bertipe-1, karena pengendali jenis ini memiliki kemampuan lebih baik dalam menekan osilasi sudut pendulum. Hal ini menghasilkan nilai IAEs (Integral Absolute Error untuk sudut) dan IAEj (Integral Absolute Error untuk posisi) yang lebih kecil. Pengendali fuzzy bertipe-2 interval juga membutuhkan sinyal kendali yang relatif lebih kecil, sebagaimana diperlihatkan oleh nilai $I A C$ (Integral Absolute Control) pada Tabel 3.

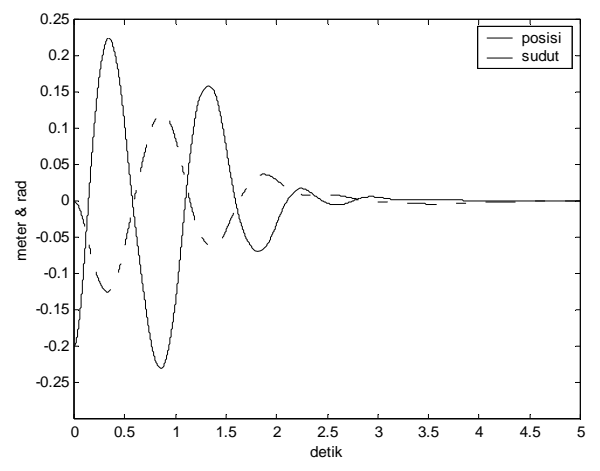

(a)

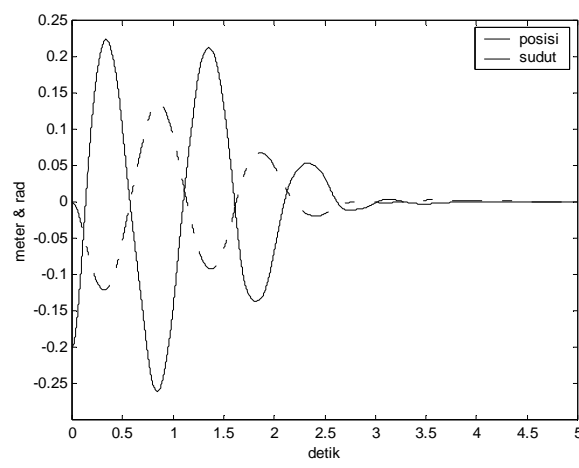

(b)

Gambar 11 Tanggapan sistem kendali inverted pendulun on cart, menggunakan pengendali adaptif: (a) fuzzy bertipe 1, (b) fuzzy bertipe 2 interval.

Tabel 3 Kinerja sistem kendali pendulum terbalik

\begin{tabular}{|c|c|c|c|}
\hline Tipe & IAE $_{\boldsymbol{s}}$ & $\boldsymbol{I A E}_{\boldsymbol{j}}$ & IAC \\
\hline Tipe-1 & 0,29 & 0,15 & 18,76 \\
\hline Tipe-2 & $\mathbf{0 , 2 4}$ & $\mathbf{0 , 1 3}$ & $\mathbf{1 4 , 7 6}$ \\
\hline
\end{tabular}

\section{Hasil Eksperimen}

Setup eksperimen sistem kendali adaptif fuzzy untuk pendulum terbalik diperlihatkan pada Gambar 8. Besarnya penguatan untuk pengendali fuzzy (arah maju) adalah $G E_{\theta}=5,19, G E_{y}=5 ; G U 1=-1,3 ; \quad G C E_{\theta}=2,75, G C E_{y}=0,75$; dan $G U 2=-1.3$. Sedangkan penguatan untuk mekanisme adaptasi (sistem fuzzy dengan arah mundur) adalah $G e_{\theta}=5,19, \quad G e_{y}=5 ; \quad$ Gp2(konstanta adaptasi $=0.004$. Lebar pita fungsi keanggotaan fuzzy bertipe- 2 interval adalah 0,3 . Hasil eksperimen ditampilkan dalam Gambar 12 untuk sistem kendali adaptif fuzzy bertipe-1 dan Gambar 13 untuk sistem fuzzy bertipe-2. Munculnya osilasi pada hasil eksperimen terutama disebabkan adanya fenomena 
nonlinieritas yang berupa saturasi dan backlash yang tidak termodelkan dalam simulasi.l. Kinerja sistem kendali yang dihasilkan ditampilkan pada Tabel 4.

Dari hasil eksperimen (Gambar 12 dan 13), dapat dilihat bahwa pengendali fuzzy adaptif bertipe-2 interval memiliki kinerja yang lebih baik dari yang bertipe-1. Dengan kondisi awal sudut adalah -0,2 radian, osilasi sudut pendulum semakin kecil, demikian juga halnya dengan posisi kereta. Tanggapan posisi kereta dengan menggunakan pengendali fuzzy adaptif bertipe-1 terlihat berosilasi dengan magnituda yang cukup besar di akhir waktu simulasi. Dari hasil eksperimen ini, dapat dilihat juga bahwa pengendali fuzzy adaptif bertipe-2 interval menghasilkan gaya yang lebih kecil (Tabel 4).
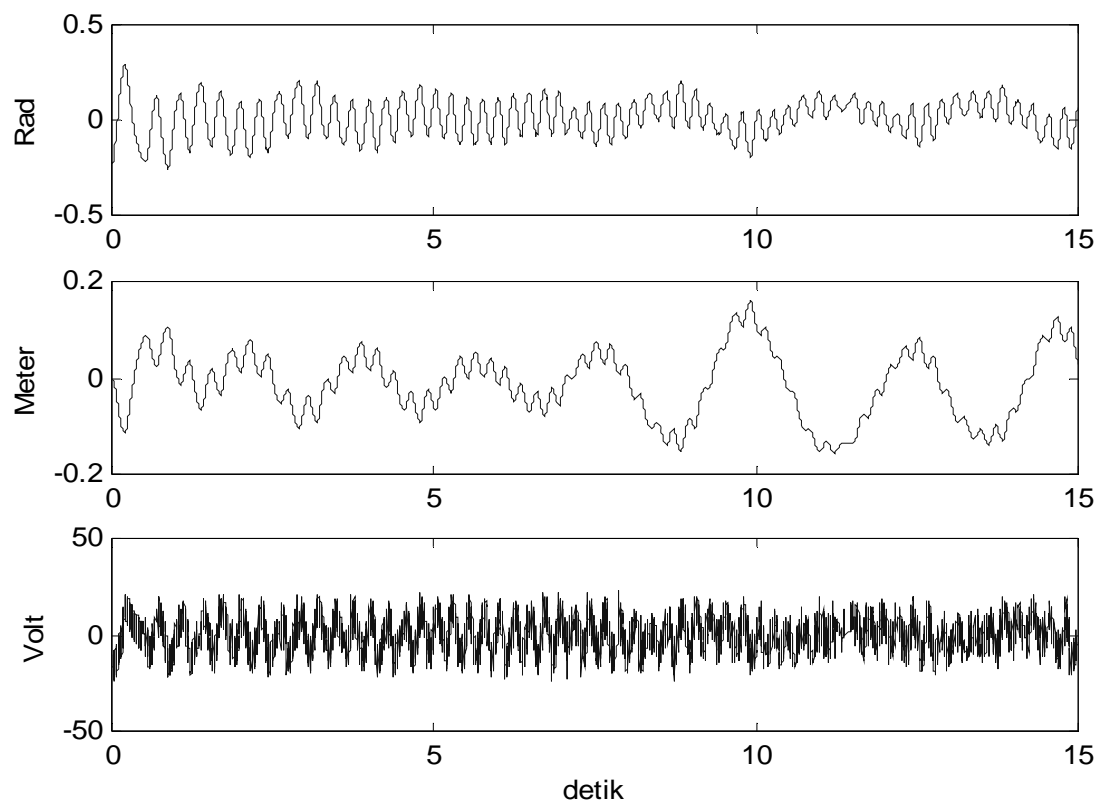

Gambar 12 Tanggapan sistem kendali pendulum terbalik, menggunakan pengendali fuzzy adaptif bertipe 1 (atas: sudut simpangan, tengah: posisi simpangan, bawah: tegangan sinyal kendali).

Tabel 4 Kinerja sistem kendali pendulum terbalik.

\begin{tabular}{|c|c|c|c|}
\hline Tipe & $\boldsymbol{I A E}_{\boldsymbol{s}}$ & $\boldsymbol{I A E}_{\boldsymbol{i}}$ & $\boldsymbol{I A C}$ \\
\hline Tipe 1 & 405,81 & 291,32 & $1.454,2$ \\
\hline Tipe 2 & $\mathbf{3 9 8 , 9 9}$ & $\mathbf{1 9 6 , 2 9}$ & $\mathbf{1 . 0 2 0 , 4}$ \\
\hline
\end{tabular}



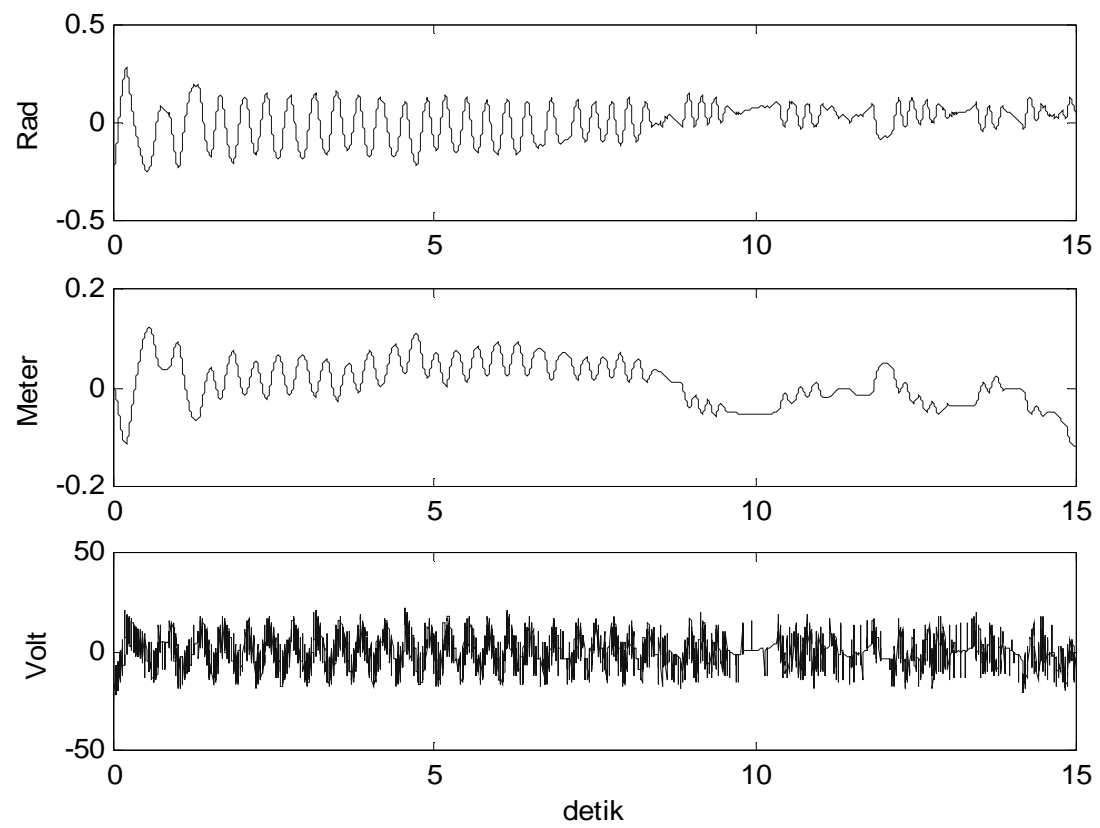

Gambar 13 Tanggapan sistem kendali pendulum terbalik, menggunakan pengendali fuzzy adaptif bertipe 2 interval (atas: sudut simpangan, tengah: posisi simpangan, bawah: tegangan sinyal kendali)

\section{Kesimpulan}

Makalah ini telah mendiskusikan metoda perancangan sistem kendali fuzzy bertipe-2 interval. Mekanisme pengendalian dilakukan secara adaptif dengan menggunakan acuan model. Berdasarkan hasil simulasi dan eksperimen pada sistem pendulum terbalik telah diperlihatkan bahwa Pengendali fuzzy adaptif bertipe-2 interval memiliki kinerja (IAEs IAEj dan $I A F$ ) yang lebih baik dibandingkan pengendali fuzzy adaptif bertipe-1. Meskipun demikian, peningkatan kinerja pada pengendali adaptif bertipe-2 ini perlu dibayar dengan beban komputasi yang relatif lebih tinggi. Penelitian lebih lanjut dapat diarahkan pada upaya mereduksi beban komputasi ini.

\section{Daftar Pustaka}

1. Karnik, N.N., Mendel, J.M., Liang, Q., Type-2 Fuzzy Logic Systems, IEEE Transactions on Fuzzy Systems, Vol. 7, hal. 643 - 658(1999).

2. Mann, George, K.I, Hu, Bao-Gang, Gosine, Raymond.G., Analysis of Direct Action Fuzzy PID Controller Structures, IEEE Transactions on Systems, Man, And Cybernetics, Vol. 29, hal 371 - 387(1999). 
3. Liang, Q., Mendel, J.M., Interval Type-2 Fuzzy Logic Systems: Theory and Design, IEEE Transactions on Fuzzy Systems, Vol. 8, 535 550(2000).

4. Mendel, J.M., John, R.I.B., Type-2 fuzzy sets made simple; IEEE Transactions on Fuzzy Systems, Vol. 10, Issue 2, hal 117-127(2002).

5. Mendel, J.M., Computing derivatives in interval type-2 fuzzy logic systems. IEEE T. Fuzzy Systems 12(1): 84-98 (2004).

6. Hagras, H.A., A hierarchical type-2 fuzzy logic control architecture for autonomous mobile robots, IEEE Transactions on Fuzzy Systems, Volume 12, hal 524-539 (2004).

7. Åström, K.J., Wittenmark, B., Adaptive Control, Addison-Wesley (1995).

8. Bosh, P.P.J. Van Den., Klauw, A.C. Van der., Modeling, Identification and Simulation of Dynamical Systems, CRC Press (1994).

9. Franklin, Gene F., Powell, J. David., Emami-Naeni, Abbas., Feedback control Of Dynamic Systems, Addison-Wesley, hal. $24-28$ (1994).

10. Jang, J.S.R., Sun, C.T., Mizutani,E., Neuro-Fuzzy and Soft Computing, Prentice-Hall International (1997).

11. Passino, K.M., Yurkovich, S., Fuzzy Control, Addison-Wesley (1998). 